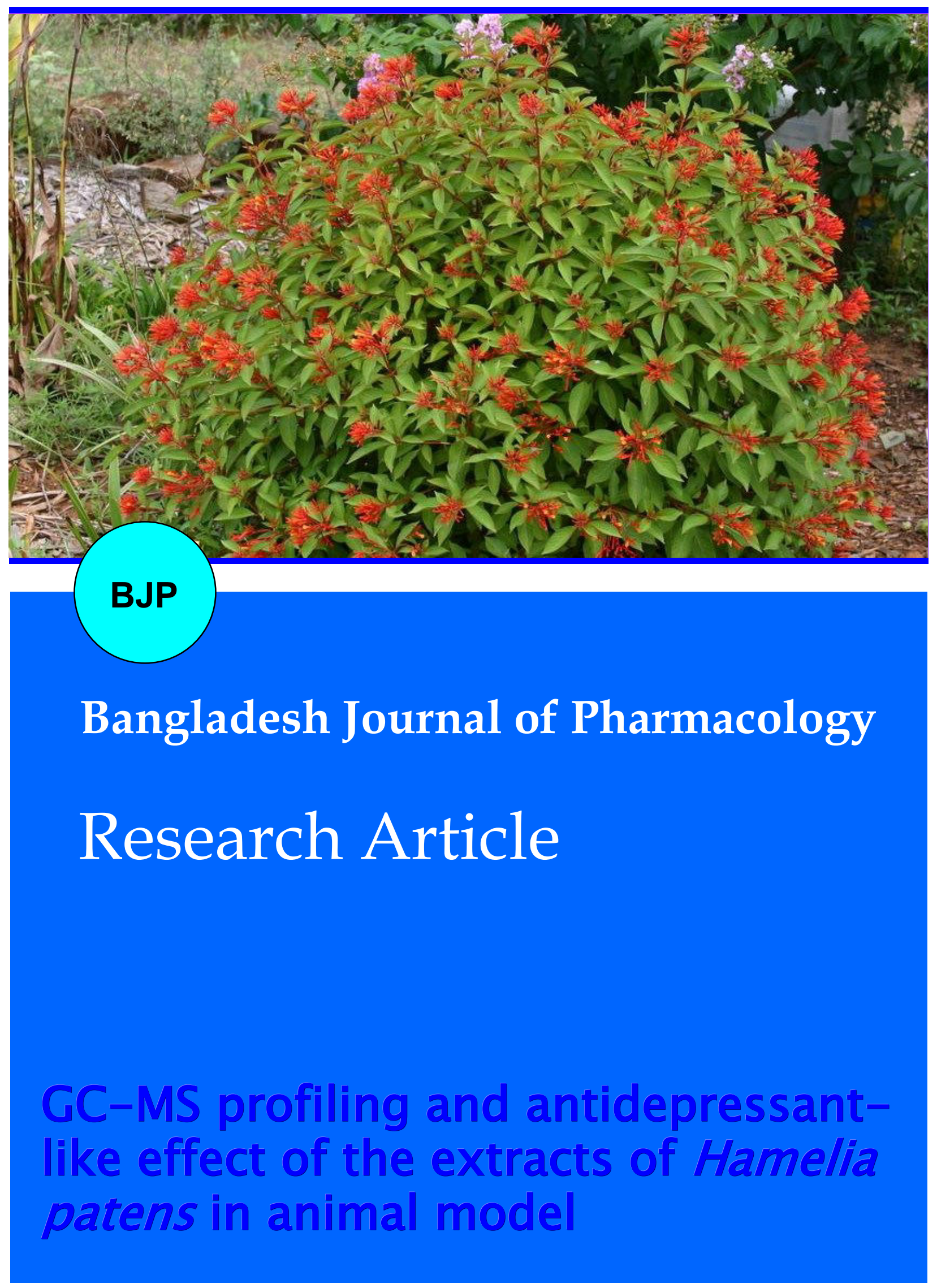


Abstracted/indexed in Academic Search Complete, Asia Journals Online, Bangladesh Journals Online, Biological Abstracts, BIOSIS Previews, CAB Abstracts, Current Abstracts, Directory of Open Access Journals, EMBASE/Excerpta Medica, Global Health, Google Scholar, HINARI (WHO), International Pharmaceutical Abstracts, Open J-gate, Science Citation Index Expanded, SCOPUS and Social Sciences Citation Index;

ISSN: $1991-0088$

\title{
GC-MS profiling and antidepressant-like effect of the extracts of Hamelia patens in animal model
}

\author{
Ajaykumar Rikhabchand Surana' and Rajendra Dayaram Wagh² \\ ${ }^{1}$ Department of Pharmacognosy, S. M. B. T. College of Pharmacy, Dhamangaon, District Nashik, M.S. 422403, \\ India; ${ }^{2}$ Department of Pharmaceutical Chemistry, A. R. A. College of Pharmacy, Dhule, M.S. 424 005, India.
}

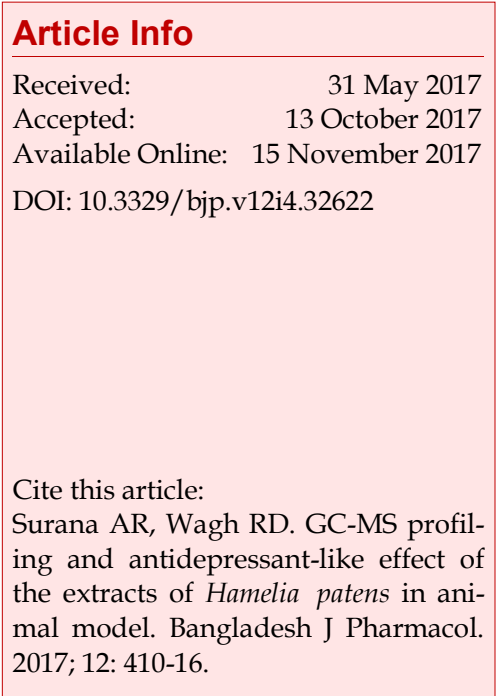

\begin{abstract}
Hamelia patens is used in folk medicine in the treatment of nervous shock. The present study deals to evaluate the antidepressant-like effects of chloroform and methanol extracts of $H$. patens on the performance of male mice and GCMS profiling of bioactive extract. Mice were given extracts orally in acute doses of 100 and $200 \mathrm{mg} / \mathrm{kg}$ daily for 7 days and then subjected to forced swim test, tail suspension test and open field test. Imipramine $(10 \mathrm{mg} / \mathrm{kg} /$ day, p.o.) and fluxetamine $(10 \mathrm{mg} / \mathrm{kg} /$ day, p.o.) were used as the standard in forced swim test and tail suspension test respectively. GC-MS profiling of chloroform extract was performed to find out the chemical constituents in bioactive fraction. After one-week treatment, the chloroform extract (100 and $200 \mathrm{mg} / \mathrm{kg} /$ day, p.o.) significantly reduced immobility time in forced swim test and tail suspension test $(\mathrm{p}<0.05)$. All extracts did not show any significant change in the locomotor activity in open field test. These data indicate that the extract of $H$. patens possesses antidepressant-like properties in mice without any significant effect on locomotor activity.
\end{abstract}

\section{Introduction}

Depression is often manifests with various symptoms at the psychological, behavioral, and physiological levels. About 350 million people are affected from this illness. Suicides can be result of the depression. It has been estimated that every year, approximately 1 million deaths occurs due to depression (WHO, 2015). To reduce symptoms of depression patient is treated with antidepressant agent. The most common adverse effects of these antidepressants includes agitation, nausea, headache, sleeplessness or drowsiness, reduced sex drive, blurred vision, bladder problem, dry mouth (Dhingra and Parle, 2012).

The unpredictable clinical response to antidepressant drugs and high susceptibility to adverse effects are the major clinical problems (Lerer and Macciardi, 2002).
Thus, new drugs are still needed to treat depressionrelated disorders. Herbal therapy is another effective alternative to treat depression. The search for novel therapeutic natural plants that mitigate depressive illness has been extensively explored over the past decade (Lavretsky, 2009; Qureshi and Al-Bedah, 2013). Thus, developing an effective and safe chemical compound that originates from traditional medicinal herbal remedies may provide a methodology to minimize adverse side effects and to shorten the entire process and reduce the cost of drug discovery compared with chemistry based drug discovery (Pan et al., 2013).

Hamelia patens Jacq. (Rubiaceae) is commonly known as firebush or scarlet bush. It is a large perennial shrub or small tree. The plants are used in folk medicine against a range of ailments. $H$. patens is used in herbal medicine 
to treat athlete's foot, skin lesions and insect bites, nervous shock, inflammation, rheumatism, headache, asthma, and dysentery (CSIR, 1959). The aerial part of H. patens contains oxindole alkaloid (Borges et al., 1979) and flavanone glycoside (Aquino et al., 1990; Suárez et al., 2008) while leaf contains ephedrine (Chaudhuri and Thakur, 1991).

From literature review, it reveals that, $H$. patens is used in folk medicine to treat nervous shock but till no scientific evaluation was carried out. The aim of present study was to perform the antidepressant activity, locomotor activity of the extracts and GC-MS analysis of bioactive extract.

\section{Materials and Methods}

\section{Authentication of plant material}

The $H$. patens stems were collected from the Nashik District in July 2014. It was identified by Dr. S. G. Kotwal, Department of Botany, K. T. H. M. College, Nashik and authenticated by Mr. A. Benniamin, Botanical Survey of India, Pune and herbarium specimen deposited as voucher No. FSC-1.

\section{Preparation of extract}

The H. patens stems were air-dried under shade avoiding exposure to direct sunlight and then pulverized in grinder. The pulverized powder (\# 60-80) material was defatted by using petroleum ether $\left(60-80^{\circ} \mathrm{C}\right)$ and defatted powder successively extracted with chloroform and methanol by continuous extraction method with the help of soxhlet apparatus. After completion of extraction, the solvent distilled out and extract was dried in a vacuum dryer (Harborne, 1998).

\section{Animals}

Male Wistar mice weighing 22-26 g were used. The animals were housed in cages at $25 \pm 2^{\circ} \mathrm{C}$ with 12 hours of a light and dark cycle and acclimatized in the experimental environment for at least 24 hours before the tests. Water and balanced diet were continually provided ad libitum, but food was not given 12 hours before the tests.

\section{Drugs and treatment}

The extract from $H$. patens was suspended in $1 \%$ acacia solution, whereas all the other drugs were dissolved in normal saline solution ( $\mathrm{NaCl} 0.9 \%$ ) immediately before use. All extracts were administered orally at a dose of 100 or $200 \mathrm{mg} / \mathrm{kg} /$ day, standard group were received fluoxetine or imipramine at a dose $10 \mathrm{mg} / \mathrm{kg} /$ day orally. The control animals received appropriate vehicle. The extracts from $H$. patens or vehicle or standard were administered by oral route (p.o.) 1 hour before the forced swimming test, tail suspension test or open field test.

\section{Oral toxicity study}

Acute oral toxicity of the extracts of $H$. patens was carried out by the up-and-down procedure. Animal was dosed, one at a time, at 24 hours intervals. Depending on outcome, the dose for the next animals is adjusted up or down. For further doses, a dose progression factor of 3.2 was used. The next dose was administered according to mortality of the animal. The dose was increased if the animal survived. After reaching dose, four additional animals was dosed the same dose (Bruce, 1985).

\section{Forced swim test (To evaluate antidepressant activity)}

All the experimental procedures were started on day 4 and day 7, 1 hour after the drug administration. Mice were individually forced to swim in an open cylindrical container (diameter $14 \mathrm{~cm}$, height $20 \mathrm{~cm}$ ), with a depth of $15 \mathrm{~cm}$ of water at $25 \pm 1^{\circ} \mathrm{C}$. The water in the containers was changed after each trial (Liu et al., 2012; Porsolt et al., 1977). Each mouse was judged to be immobile during $6 \mathrm{~min}$. Immobility in forced swimming test was defined as the animals ceased struggling and remained floating motionless in the water, making only those movements necessary to keep its head above water.

\section{Tail suspension test (To evaluate antidepressant activity)}

Mice were suspended $50 \mathrm{~cm}$ above the floor by adhesive tape placed approximately $1 \mathrm{~cm}$ from the tip of the tail. The total immobility period was scored manually during $6 \mathrm{~min}$. Immobility in tail suspension test was defined as the absence of any limb or body movements, except for those caused by respiration or when they hung passively and completely motionless (Rosa et al., 2008; Zeni et al., 2013). The parameter obtained was the number of seconds spent immobile.

\section{Evaluation of locomotor activity}

The locomotor activity was performed by open field test in order to detect any link between antidepressant activity and the locomotor and exploratory activities of the $H$. patens extracts. The open field test was performed on mice $(n=6)$ which received those treatments that used to determine immobility time in forced swimming test/tail suspension test 1 hour before being observed in the open field. Animals were individually placed in a box $(30 \times 30 \times 15 \mathrm{~cm})$, with the floor divided into 9 equal squares. After the habituation to the arena for 5 min, ambulation/locomotor activity (the number of squares crossed with all paws), number of grooming and rearing events were observed for 6 min (HerreraRuiz et al., 2006; Wang et al., 2013). The box was cleaned with $10 \%$ ethanol after each trial. 
Phytochemical investigation of bioactive extracts by gas chromatography-mass spectrometry (GC-MS)

The bioactive extract of $H$. patens was analyzed by the GC-MS technique and performed at SAIF Panjab University Chandigarh, India. The chemical composition of the crude extracts was determined using an Thermo Scientific TSQ 8000 gas chromatograph-mass spectrometer with a direct capillary interface fused with silica capillary column TG 5MS (30 m X $0.25 \mathrm{~mm}, 0.25$ $\mu \mathrm{m})$. Samples were injected under the following conditions: Helium was used as carrier gas at constant rate $1 \mathrm{~mL} / \mathrm{min}$, pulsed splitless mode. The solvent delay was $2 \mathrm{~min}$ and the injection size was $1.0 \mu \mathrm{L}$. The mass-spectrophotometric detector was operated in the electron impact ionization mode with an ionizing energy of $70 \mathrm{eV}$ and scanning from $\mathrm{m} / \mathrm{z} 50-500$. The GC temperature program started at $60^{\circ} \mathrm{C}$, then elevated to $280^{\circ} \mathrm{C}$ at a rate of $10^{\circ} \mathrm{C} / \mathrm{min}$, with a $10 \mathrm{~min}$ hold at $280^{\circ}$ C. The injector, ion source and detector temperatures were set at 250,230 and $280^{\circ} \mathrm{C}$, respectively (Abdel-Aal et al., 2015; Al-Owaisi et al., 2014). The peaks separated in GC-MS were identified by NIST (National Institute of Standards and Technology) mass spectral databases.

\section{Statistical analysis}

All experimental results are given as the mean \pm standard error of the mean (SEM). To compare test and control groups one-way analysis or two-way analysis of variance (ANOVA), followed by Dunnett's test was used. A value of $\mathrm{p}<0.05$ was considered to be significant.

\section{Results}

\section{Oral toxicity study}

The oral toxicity study was carried out by up-and-down procedure on male mice. The $250 \mathrm{mg} / \mathrm{kg}$ of the extract was given to first animal. In 24 hours, mortality not showed by that animal. The next dose of the extract was given to another animal which also not showed mortality in 24 hours. The same procedure was performed for 2,000 mg/ $\mathrm{kg}$ in other animal. The extract did not show any mortality for next four animals also. The dose was finalized to 200 and $100 \mathrm{mg} / \mathrm{kg}$ due to animals not shown toxicity in dose $2,000 \mathrm{mg} / \mathrm{kg}$ of the extract.

\section{Effects of extract on the immobility time in the forced swimming test}

The chloroform extract induced a significant antidepressant effect in the forced swimming test
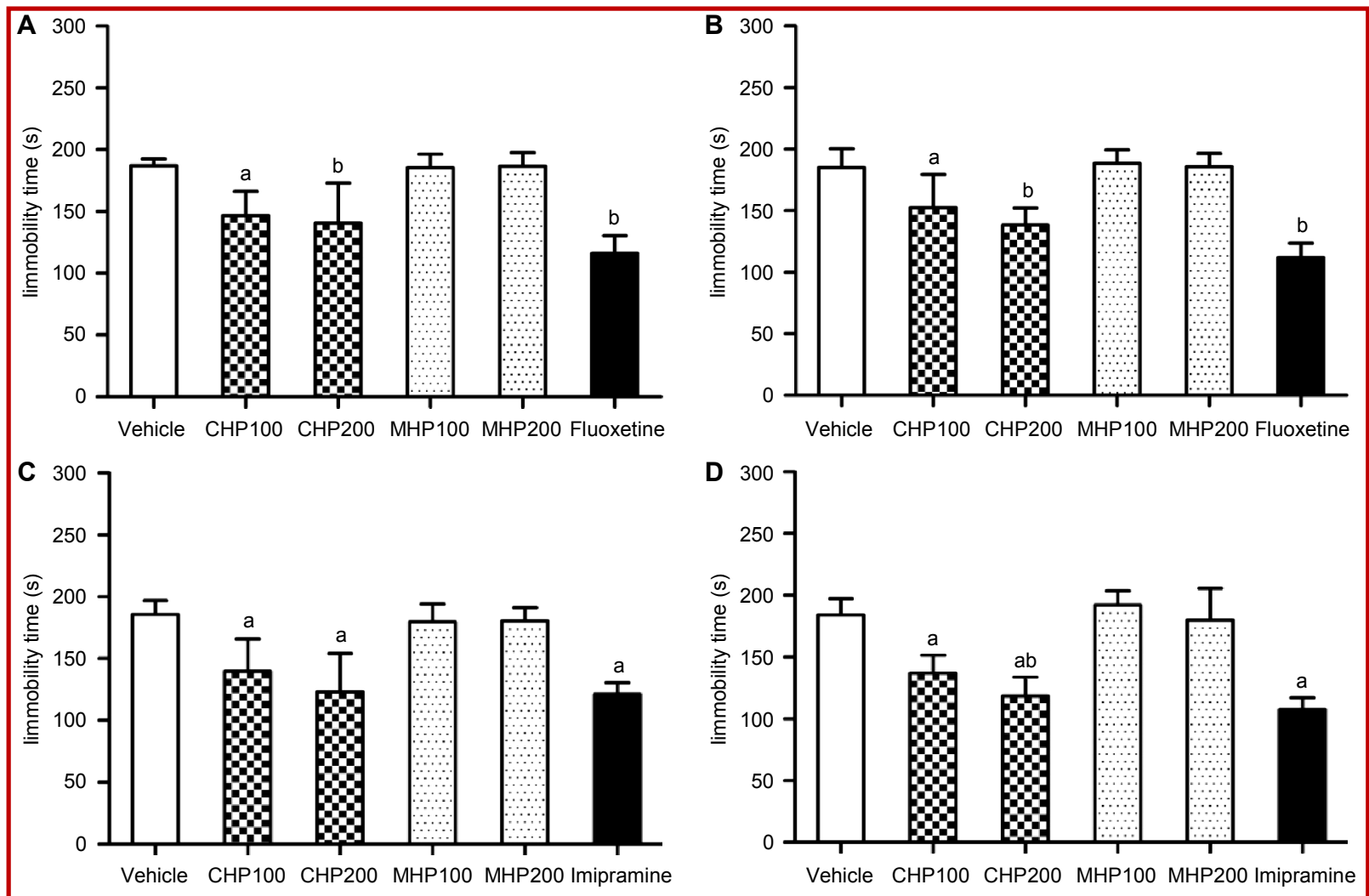

Figure 1: Effects of $H$. patens extracts (100 and $200 \mathrm{mg} / \mathrm{kg})$, or standard $(10 \mathrm{mg} / \mathrm{kg})$ for 4 days $(\mathrm{A}, \mathrm{C})$ and 7 days (B,D) administration on the immobility time in the forced swim test $(\mathrm{A}, \mathrm{B})$ and tail suspension test $(\mathrm{C}, \mathrm{D})$. The results are expressed as the mean \pm SEM, $n=6$ in each group. ap $<0.01,{ }^{b} p<0.001$ VS the vehicle-treated control group. (CHP- Chloroform extract of H. patens, MHPMethanol extract of H. patens) 


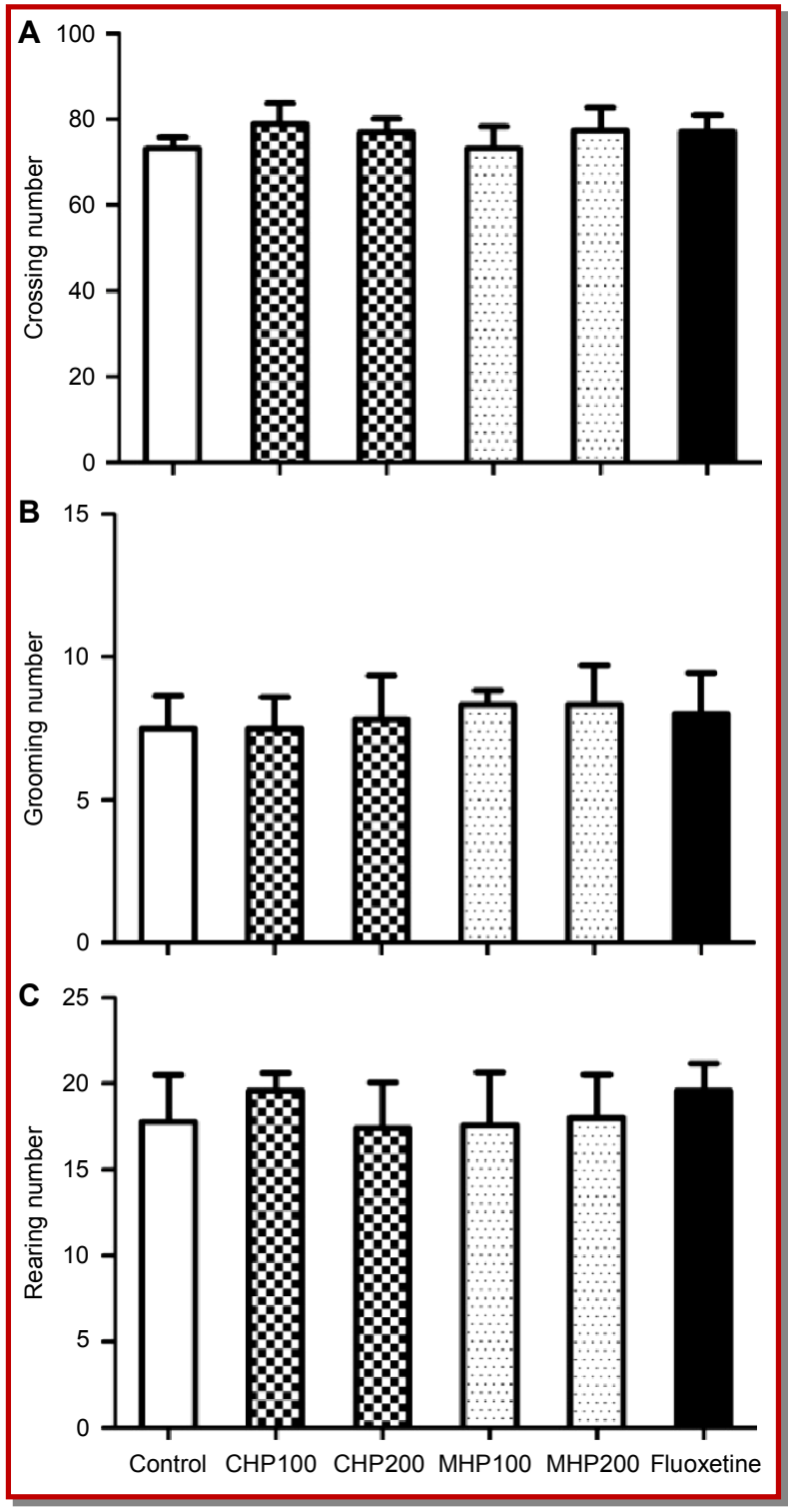

Figure 2: Effects of $H$. patens extracts (100 and $200 \mathrm{mg} / \mathrm{kg}$ ), or fluoxetine $(10 \mathrm{mg} / \mathrm{kg})$ for 7 days administration on the number of crossing, rearing and grooming in open field test. The results are expressed as the mean \pm SEM, $n=6$ in each group. (CHPChloroform extract of $H$. patens, MHP-Methanol extract) because it significantly reduced the immobility time compared with the vehicle treated group (185.2 \pm 6.2 sec) (Figure 1). On the contrary, the methanol extract did not give this behavior. The immobility time of chloroform extract was found to be $152.7 \pm 11.0,138.3 \pm$ $5.7 \mathrm{sec}$ and for methanol extract $185.3 \pm 4.3,186.5 \pm 4.3$ sec for the doses of 100 and $200 \mathrm{mg} / \mathrm{kg} /$ day on day 7 day respectively. The standard group treated with fluoxetine $(10 \mathrm{mg} / \mathrm{kg})$ exhibited powerful activity $(111.8 \pm 4.8 \mathrm{sec})$. No significant difference observed in immobility time of the extracts on day 4 and day 7 in forced swimming test.

\section{Effects of extract on the immobility time in the tail suspension test}

In the tail suspension test, the chloroform extract showed a significant effect on decreasing the immobility time, compared with the vehicle-treated control group (184.2 $\pm 5.4 \mathrm{sec}$ ) (Figure 1). The mean immobility time of the chloroform extract-treated group for 100 and $200 \mathrm{mg} / \mathrm{kg}$ dose was $137.2 \pm 5.9$ and $118.7 \pm 6.5 \mathrm{sec}$, respectively. While methanol extract did not show any effect on the immobility time $(192.2 \pm 4.7,176.8 \pm 10.5$ $\mathrm{sec})$. Chloroform extract of $200 \mathrm{mg} / \mathrm{kg}$ showed a significant effect when compared with $200 \mathrm{mg} / \mathrm{kg}$ dose $(\mathrm{p}<0.05)$. The standard group treated with imipramine $(10 \mathrm{mg} / \mathrm{kg})$, also significantly diminished the immobility time $(107.7 \pm 3.8 \mathrm{sec})$. No significant difference was observed in the immobility time of the extract on day 4 and day 7 in the tail suspension test.

\section{Effects of extract on the open field test}

No significant differences were observed in the number of squares crossed, rearing and grooming between vehicle treated group and $H$. patens extracts as well as the standard treated groups $(\mathrm{p}<0.05)$ (Figure 2).

\section{GC-MS analysis of bioactive chloroform extract}

The results pertaining to GC-MS analysis lead to the identification of number of compounds from GC fractions of the bioactive chloroform extract of $H$. patens. They were identified through mass spectrometry attached with GC. GC-MS analysis of the chloroform extract of $H$. patens is shown in Table I. The GC-MS

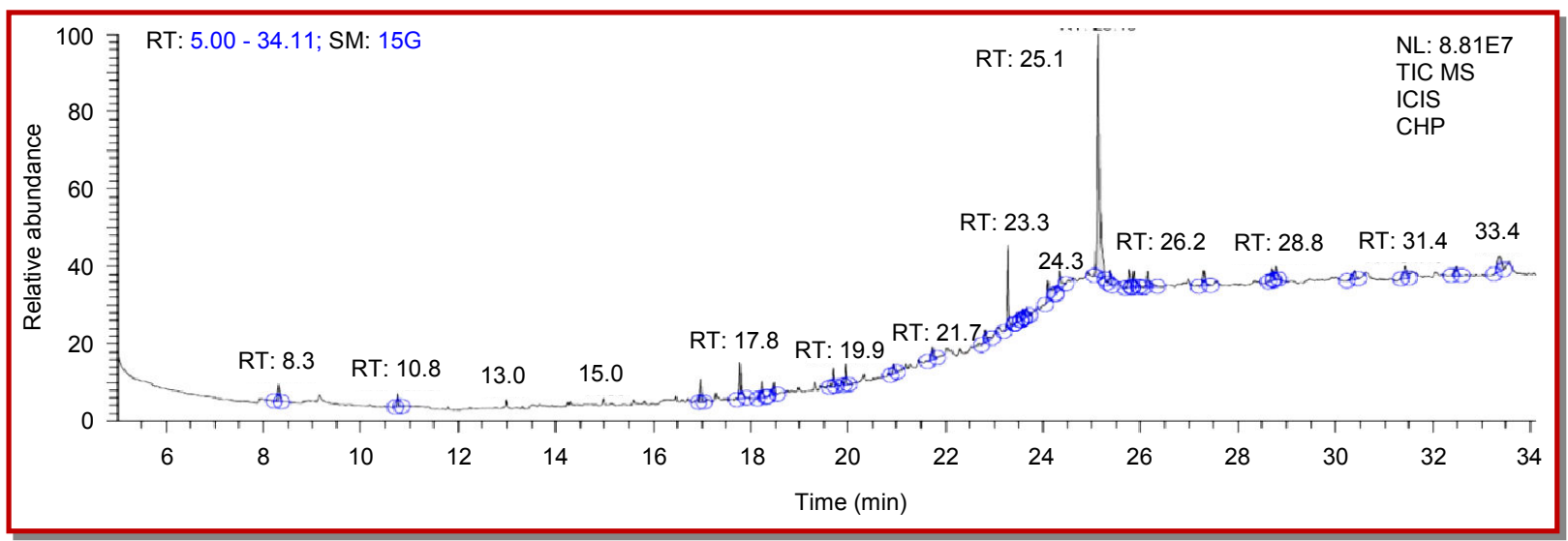

Figure 3: GC-MS chromatogram chloroform extract of Hamelia patens 


\begin{tabular}{|c|c|c|c|c|}
\hline \multicolumn{5}{|c|}{ Table I } \\
\hline \multicolumn{5}{|c|}{$\begin{array}{l}\text { Compounds present in the chloroform extract of Hamelia } \\
\text { patens using GC-MS profiling }\end{array}$} \\
\hline $\begin{array}{c}\mathrm{Rf} \\
(\mathrm{min})\end{array}$ & Name of compound & $\begin{array}{l}\text { Molecular } \\
\text { formula }\end{array}$ & MW & $\%$ \\
\hline 17.8 & Methyl palmitate & $\mathrm{C}_{17} \mathrm{H}_{34} \mathrm{O}_{2}$ & 270.5 & 4.0 \\
\hline 18.2 & Dibutyl phthalate & $\mathrm{C}_{16} \mathrm{H}_{22} \mathrm{O}_{4}$ & 278.3 & 2.0 \\
\hline 18.5 & Eicosane & $\mathrm{C}_{20} \mathrm{H}_{42}$ & 282 & 1.6 \\
\hline 19.7 & Methyl stearate & $\mathrm{C}_{19} \mathrm{H}_{38} \mathrm{O}_{2}$ & 298 & 1.7 \\
\hline 20.0 & Bis(2-ethylhexyl) maleate & $\mathrm{C}_{20} \mathrm{H}_{36} \mathrm{O}_{4}$ & 340.5 & 1.6 \\
\hline 20.9 & $\begin{array}{l}5 \beta \text {-Cholestan-3-one eth- } \\
\text { ylene acetal }\end{array}$ & $\mathrm{C}_{29} \mathrm{H}_{50} \mathrm{O}_{2}$ & 430 & 1.2 \\
\hline 21.7 & $\begin{array}{l}4,8,12,16- \\
\text { Tetramethylheptadecan-4- } \\
\text { olide }\end{array}$ & $\mathrm{C}_{21} \mathrm{H}_{40} \mathrm{O}_{2}$ & 324 & 1.7 \\
\hline 23.3 & $\begin{array}{l}\text { Bis(2-propylpentyl) } \\
\text { phthalate }\end{array}$ & $\mathrm{C}_{24} \mathrm{H}_{38} \mathrm{O}_{4}$ & 390 & 7.5 \\
\hline 23.5 & $\begin{array}{l}\text { 3-Acetoxy -7,8- } \\
\text { epoxylanostan-11-ol }\end{array}$ & $\mathrm{C}_{32} \mathrm{H}_{54} \mathrm{O}_{4}$ & 502 & 1.6 \\
\hline 23.6 & $\begin{array}{l}\text { Oleic acid 3(octadecyloxy) } \\
\text { propyl ester }\end{array}$ & $\mathrm{C}_{39} \mathrm{H}_{76} \mathrm{O}_{3}$ & 592 & 1.6 \\
\hline 23.7 & Oleic acid, eicosyl ester & $\mathrm{C}_{38} \mathrm{H}_{74} \mathrm{O}_{2}$ & 562.6 & 1.2 \\
\hline 24.1 & $\begin{array}{l}\text { Methyl 2- } \\
\text { hydroxydocosanoate }\end{array}$ & $\mathrm{C}_{23} \mathrm{H}_{46} \mathrm{O}_{3}$ & 370 & 4.6 \\
\hline 25.1 & (Z)-13-Docosenamide & $\mathrm{C}_{22} \mathrm{H}_{43} \mathrm{~N}_{\mathrm{O}}$ & 337.6 & 33.0 \\
\hline 25.4 & $\begin{array}{l}\text { Vobasan-17-oic acid, 4- } \\
\text { demethyl-3-oxo-, methyl } \\
\text { ester (Perivine) }\end{array}$ & $\mathrm{C}_{20} \mathrm{H}_{22} \mathrm{~N}_{2} \mathrm{O}_{3}$ & 338.4 & 1.4 \\
\hline 25.8 & $\begin{array}{l}\text { 6,7-Didehydro-1,3- } \\
\text { dimethyl-2alpha,20- } \\
\text { cycloaspidospermidine }\end{array}$ & $\mathrm{C}_{21} \mathrm{H}_{26} \mathrm{~N}_{2}$ & 306.4 & 2.3 \\
\hline 25.9 & $\begin{array}{l}\text { Methyl 2- } \\
\text { hydroxytetracosanoate }\end{array}$ & $\mathrm{C}_{26} \mathrm{H}_{44} \mathrm{O}_{5}$ & 398.7 & 2.1 \\
\hline 28.8 & $\begin{array}{l}\text { 9,19-Cyclochloestene-3,7- } \\
\text { diol, 4,14-dimethyl-, 3- } \\
\text { acetate }\end{array}$ & $\mathrm{C}_{31} \mathrm{H}_{52} \mathrm{O}_{3}$ & 472.8 & 1.8 \\
\hline 30.4 & Tetratriacontane & $\mathrm{C}_{34} \mathrm{H}_{70}$ & 478.9 & 1.8 \\
\hline 31.4 & $\begin{array}{l}\beta \text {-Campesteryl-D- } \\
\text { glucoside }\end{array}$ & $\mathrm{C}_{34} \mathrm{H}_{58} \mathrm{O}_{6}$ & 562.8 & 2.6 \\
\hline 33.5 & $\beta$-Sitosteryl-D-glycoside & $\mathrm{C}_{35} \mathrm{H}_{60} \mathrm{O}_{6}$ & 576.8 & 3.8 \\
\hline
\end{tabular}

\section{Discussion}

The present work investigated for the antidepressant activity of chloroform and methanol extract of $H$. patens. The chloroform extract decreases immobility time while methanol extract doesn't showed any effect in tail suspension test and forced swim test. The chloroform extract gave dose dependent activity. We also investigated locomotor activity of extracts of $H$. patens in mice by open field test. The chloroform and methanol extract of $H$. patens does't show any significant changes in locomotor activity. The bioactive chloroform extract of $H$. patens was analyzed by GC-MS and showed that extract contains fatty acid or esters, indole alkaloids, amides, steroidal glycoside and saponins.

In our study, we investigated antidepressant and locomotor activity of extracts of $H$. patens in mice for the first time and the extract was analyzed by GC-MS as no information was found in literature.

The immobility in tail suspension and forced swim test referred to as behavioral despair in animals and is believed to reproduce a condition similar to depression in human (MacHado et al., 2013). The compounds which able to increases locomotor activity in open field test including psychostimulants, convulsants and anticholinergics give a false positive result in tail suspension and forced swim test (Farah Idayu et al., 2011). In general, hyperkinesis also produces false positive effect in immobility time (Freitas et al., 2010). Therefore, open field test was carried out to justify false positive effects that could be associated with psychostimulants, convulsants and anticholinergics or hyperkinesis (Kwon et al., 2010). The antidepressants would not affect on locomotor activity (Borsini and Meli, 1988). In addition, this finding suggested that reduction of

spectra (Figure 3) indicated the presence of 20 different phytoconstituents i.e. methyl palmitate $(4.0 \%)$, dibutyl phthalate $(2.0 \%)$, eicosane $(1.6 \%)$, methyl stearate $(1.7 \%)$, bis(2-ethylhexyl) maleate $(1.6 \%), 5 \beta$-cholestan-3one ethylene acetal (1.2\%), 4,8,12,16-tetramethylheptadecan-4-olide (1.7\%), bis(2-propylpentyl) phthalate (7.5\%), 3-acetoxy-7,8-epoxylanostan-11-ol (1.6\%), oleic acid 3-(octadecyloxy)propyl ester (1.6\%), oleic acid, eicosyl ester $(1.2 \%)$, methyl 2-hydroxydocosanoate $(4.6 \%)$, (Z)-13-docosenamide $(33.0 \%)$, vobasan-17-oic acid, 4-demethyl-3-oxo-, methyl ester (perivin) (1.4\%), 6,7-didehydro-1,3-dimethyl-2alpha,20-cycloaspidospermidine $(2.3 \%)$, methyl 2-hydroxytetracosanoate $(2.1 \%)$, 9,19-cyclochloestene-3,7-diol, 4,14-dimethyl-, 3-acetate $(1.8 \%)$, tetratriacontane $(1.8 \%), \beta$-campesteryl-D-glucoside $(2.6 \%)$ and $\beta$-sitosteryl-D-glucoside (3.8\%). immobility time elicited by chloroform extract in forced swim test as well as tail suspension test was specifically arises via its antidepressant mechanism. As per literature, indole alkaloids, amides and steroidal components show antidepressant activity (Hamid, 2017). The above constituents were also present in chloroform extract of $H$. patens which may be responsible for antidepressant activity. H. patens stem are used in folk medicine to treat nervous shock and our investigation also supports to treat nervous disorders.

\section{Conclusion}

Administration of chloroform extract of $H$. patens 
extract is able to produce an antidepressant-like effect, which not due to effect of psychostimulant or hyperkinesias confirmed by open field test. The chloroform extracts of $H$. patens stems showed antidepressant activity supporting use in traditional medicine to treat nervous shock.

\section{Ethical Issue}

The animal experimental were performed in accordance with the guidelines for the care and use of laboratory animals, of the CPCSEA, India and approved by the Institutional Animal ethical committee (1329/ac/10/CPCSEA).

\section{Conflict of Interest}

Authors declare no conflict of interest.

\section{Acknowledgement}

Authors are thankful to Principal, SMBT College of Pharmacy, Dhamangaon, India for providing necessary facilities. Authors are also thankful to SAIF Panjab University Chandigarh, India for providing GC-MS facilities.

\section{References}

Abdel-Aal EI, Haroon AM, Mofeed J. Successive solvent extraction and GC-MS analysis for the evaluation of the phytochemical constituents of the filamentous green alga Spirogyra longata. Egypt J Aquat Res. 2015; 41: 233-46.

Al-Owaisi M, Al-Hadiwi N, Khan SA. GC-MS analysis, determination of total phenolics, flavonoid content and free radical scavenging activities of various crude extracts of Moringa peregrina (Forssk.) Fiori leaves. Asian Pac J Trop Biomed. 2014; 4: 964-70.

Aquino R, Ciavatta ML, De Simone F, Pizza C. A flavanone glycoside from Hamelia patens. Phytochemistry 1990; 29: 2359 $-60$

Borges J, Manresa MT, Martín Ramón JL, Pascual C, Rumbero A. Two new oxindole alkaloids isolated from Hamelia patens Jacq. Tetrahedron Lett. 1979; 20: 3197-200.

Borsini F, Meli A. Is the forced swimming test a suitable model for revealing antidepressant activity? Psychopharmacology (Berl). 1988; 94: 147-60.

Bruce RD. An up-and-down procedure for acute toxicity testing. Fundam Appl Toxicol. 1985; 5: 151-57.

Chaudhuri P, Thakur S. Hamelia patens: A new source of ephedrine. 1991; 7: 199.

CSIR. The Wealth of India: A Dictionary of Indian raw materials and industrial products. 1st ed. New Delhi, India, Council of Scientific Industrial Research (CSIR), 1959; 5.

Dhingra S, Parle M. Herbal remedies and nutritional supplements in the treatment of depression: A systematic review. Bull Clin Psychopharmacol. 2012; 22: 1.

Farah Idayu N, Taufik Hidayat M, Moklas MAM, Sharida F, Nurul Raudzah AR, Shamima AR, Antidepressant-like effect of mitragynine isolated from Mitragyna speciosa Korth in mice model of depression. Phytomedicine 2011; 18: 402-07.

Freitas AE, Budni J, Lobato KR, Binfaré RW, Machado DG, Jacinto J, Veronezi PO, Pizzolatti MG, Rodrigues AL. Antidepressant-like action of the ethanolic extract from Tabebuia avellanedae in mice: Evidence for the involvement of the monoaminergic system. Prog Neuro-Psychopharmacol Biol Psychiatry. 2010; 34: 335-43.

Hamid HA, Ramli ANM, Yusoff MM. Indole alkaloids from plants as potential leads for antidepressant drugs: A mini review. Front Pharmacol. 2017; 8: 96.

Harborne JB. Phytochemical Methods: A guide to modern techniques of plant analysis. 5th ed., Chapman \& Hall, London, 1998.

Herrera-Ruiz M, García-Beltrán Y, Mora S, Díaz-Véliz G, Viana GSB, Tortoriello J, Ramirez G. Antidepressant and anxiolytic effects of hydroalcoholic extract from Salvia elegans. J Ethnopharmacol. 2006; 107: 53-58.

Kwon S, Lee B, Kim M, Lee H, Park HJ, Hahm DH. Antidepressant-like effect of the methanolic extract from Bupleurum falcatum in the tail suspension test. Prog NeuroPsychopharmacol Biol Psychiatry. 2010; 34: 265-70.

Lavretsky H. Complementary and alternative medicine use for treatment and prevention of late-life mood and cognitive disorders. Aging Health. 2009; 5: 61-78.

Lerer B, Macciardi F. Pharmacogenetics of antidepressant and mood-stabilizing drugs: A review of candidate-gene studies and future research directions. Int $J$ Neuropsychopharmacol . 2002; 5: 255-75.

Liu J, Qiao W, Yang Y, Ren L, Sun Y, Wang S. Antidepressantlike effect of the ethanolic extract from Suanzaorenhehuan formula in mice models of depression. J Ethnopharmacol. 2012; 141: 257-64.

MacHado DG, Cunha MP, Neis VB, Balen GO, Colla A, Bettio LEB. Antidepressant-like effects of fractions, essential oil, carnosol and betulinic acid isolated from Rosmarinus officinalis L. Food Chem. 2013; 136: 999-1005.

Pan SY, Zhou SF, Gao SH, Yu ZL, Zhang SF, Tang MK, Sun JN, Ma DL, Han YF, Fong WF, Ko KM. New perspectives on how to discover drugs from herbal medicines: CAM's outstanding contribution to modern therapeutics. Evid Based Complement Alternat Med. 2013; 2013: 627375.

Porsolt RD, Bertin A, Jalfre M. Behavioral despair in mice: A primary screening test for antidepressants. Arch Int Pharmacodyn Ther. 1977; 229: 327-36.

Qureshi NA, Al-Bedah AM. Mood disorders and complementary and alternative medicine: A literature review. Neuropsychiatr Dis Treat. 2013; 9: 639-58.

Rosa AO, Kaster MP, Binfaré RW, Morales S, Martín-Aparicio E, Navarro-Rico ML, Martinez A, Medina M, García AG, López MG, Rodrigues AL. Antidepressant-like effect of 
the novel thiadiazolidinone NP031115 in mice. Prog NeuroPsychopharmacol Biol Psychiatry. 2008; 32: 1549-56.

Suárez AI, Diaz B, Tillett S, B EV, Compagnone RS. Leishmanicidal activity of alkaloids from Hamelia patens. Ciencia. 2008; 16: 148-55.

Wang Z, Gu J, Wang X, Xie K, Luan Q, Wan N, Zhang Q, Jiang $\mathrm{H}$, Liu D. Antidepressant-like activity of resveratrol treatment in the forced swim test and tail suspension test in mice:
The HPA axis, BDNF expression and phosphorylation of ERK. Pharmacol Biochem Behav. 2013; 112: 104-10.

WHO. Fact Sheet of depression, N`369. Geneva: World Health Organization, 2015.

Zeni ALB, Zomkowski ADE, Maraschin M, Tasca CI, Rodrigues ALS. Evidence of the involvement of the monoaminergic systems in the antidepressant-like effect of Aloysia gratissima. J Ethnopharmacol. 2013; 148: 914-20. 